\title{
Long-term changes in the trophic state of Suwalki lakes - an analysis by means of indices based on abundance and composition of their rotifer fauna
}

\author{
Jolanta Ejsmont-Karabin ${ }^{1^{*}}$, Andrzej Górniak², Elżbieta Jekatierynczuk-Rudczyk², Maciej Karpowicz ${ }^{2}$, \\ Adam Więcko ${ }^{2}$ \\ ${ }^{1}$ Nencki Institute of Experimental Biology, Polish Academy of Sciences, Pasteura 3, 02-093 Warszawa, Poland; \\ e-mail: j.karabin@nencki.gov.pl (*corresponding author) \\ ${ }^{2}$ University of Bialystok, Institute of Biology, Ciołkowskiego 1J, 15-245 Bialystok, Poland
}

\begin{abstract}
Rotifer abundance and species composition in lakes of the Suwalki Landscape Park were studied in the years 1983-1985, 2009, 2012 and 2015. Rotifer trophic state indices $\left(\mathrm{TSI}_{\mathrm{ROT}}\right.$ ) were used to assess changes in the trophic state of the studied lakes. In most lakes of the Suwalki Landscape Park, there were no changes in rotifer communities over the 25-32 year period to indicate a decline in trophy of the lakes. However, in lakes with the strongest decline in TSI $_{\text {ROT }}$ values, the values of indicative parameters widely varied in 2015 , which may indicate that the status of rotifer communities in the lakes may be dependent on non-trophic factors.
\end{abstract}

Key words: Rotifera, zooplankton, lakes, trophic state index

\section{Introduction}

Summer communities of rotifers (Rotifera) in harmonic lakes are primarily controlled by availability of food, so they usually react strongly to changes in trophic status of lakes by changes in the community density as well as species composition (Gannon and Stemberger 1978; Ejsmont-Karabin 2012, 2013; Haberman and Haldna 2014; Ochocka and Pasztaleniec 2016). Long-term observations of rotifer fauna in lakes of The Great Masurian Lake system (Ejsmont-Karabin 2013) showed that rotifers are a very sensitive group as regards their response to both increase and decrease in lake trophy. The studies also indicate the high sensitivity of the GML system to anthropogenic changes in their watershed. The aim of the studies concerning rotifer communities in lakes of the Suwałki Landscape Park was to use the above-mentioned features of rotifer zooplankton for assessing the recent trophic status of the studied lakes as well as long-term trends in changes of their trophy.

The region under study is a diverse natural landscape which seems to retain a natural rate of eutrophication not accelerated by agriculture, settlement or tour- ism (Jekatierynczuk-Rudczyk et. al. 204). As a result most of the lakes are characterized by low chlorophylla concentrations and low content of cyanoprokaryotes (Karpowicz et.al. 2016). The process of eutrophication of the lakes situated in this area should, therefore be rather slow. Thus the tested hypothesis proposes that the trophic status of the studied lakes is low and has remained unchanged for the last 30 years.

\section{Material and methods}

The studied lakes are as diverse as their watersheds and include typical deep channel lakes, moraine lakes and shallow polymictic lakes. As a result, the set of these lakes is extremely differentiated as regards their area and depth (Table 1).

Samples were taken in July/August 1983-1985, 2009, 2012 and 2015 at the deepest points of the lakes. Rotifer zooplankton was sampled with a 2-1 sampler at every $1 \mathrm{~m}$ depth and pooled for layers of epi-, meta- and hypolimnion in stratified lakes and from the surface to the bottom in shallow lakes. The samples were concentrated with a plankton net of $30 \mu \mathrm{m}$ mesh size and fixed in $4 \%$ formalin. 
Table 1. Morphometric characteristics of lakes of the Suwałki Landscape Park (data according to Borowiak et al. 2016 and Jańczak 1999)

\begin{tabular}{|c|c|c|c|c|c|}
\hline \multirow{2}{*}{ Lake } & \multicolumn{2}{|c|}{ Geographical coordinates } & \multirow{2}{*}{ Area [ha] } & \multirow{2}{*}{ Maximum depth [m] } & \multirow{2}{*}{ Mean depth $[\mathrm{m}]$} \\
\hline & Latitude & Longitude & & & \\
\hline Łuśnin & $54^{\circ} 16.7^{\prime}$ & $22^{\circ} 53.0^{\prime}$ & 0.47 & 3.0 & 1.5 \\
\hline Purwinek & $54^{\circ} 16.9^{\prime}$ & $22^{\circ} 53.9^{\prime}$ & 0.44 & 3.3 & 1.5 \\
\hline Purwin & $54^{\circ} 16.8^{\prime}$ & $22^{\circ} 53.5^{\prime}$ & 1.41 & 4.3 & 2.8 \\
\hline \multicolumn{6}{|c|}{ Drainage basin of Czarna Hańcza } \\
\hline Boczniel & $54^{\circ} 15.6^{\prime}$ & $22^{\circ} 49.3^{\prime}$ & 19.2 & 3.9 & 1.3 \\
\hline Jegliniszki & $54^{\circ} 18.9^{\prime}$ & $22^{\circ} 51.1^{\prime}$ & 16.0 & 2.4 & 1,2 \\
\hline Hańcza & $54^{\circ} 15.9^{\prime}$ & $22^{\circ} 48.7^{\prime}$ & 303.6 & 105.6 & 39.1 \\
\hline \multicolumn{6}{|c|}{ Drainage basin of Szelmentka } \\
\hline Szelment Wielki & $54^{\circ} 13.6^{\prime}$ & $22^{\circ} 58.6^{\prime}$ & 356.1 & 45.0 & 15.0 \\
\hline Szelment Mały & $54^{\circ} 15.4^{\prime}$ & $23^{\circ} 01.2^{\prime}$ & 168.5 & 28.5 & 7.5 \\
\hline Iłgieł & $54^{\circ} 16.3^{\prime}$ & $23^{\circ} 02.8^{\prime}$ & 17.1 & 9.7 & 4.1 \\
\hline Kupowo & $54^{\circ} 18.4^{\prime}$ & $23^{\circ} 02.6^{\prime}$ & 32.8 & 13.2 & 5.0 \\
\hline \multicolumn{6}{|c|}{ Drainage basin of Szeszupa } \\
\hline Czarne & $54^{\circ} 17.6^{\prime}$ & $22^{\circ} 54.1^{\prime}$ & 16.2 & 11.2 & 2.8 \\
\hline Gulbin & $54^{\circ} 15.6^{\prime}$ & $22^{\circ} 54.0^{\prime}$ & 7.4 & 9.1 & 3.5 \\
\hline Jaczno & $54^{\circ} 16.6^{\prime}$ & $22^{\circ} 52.3^{\prime}$ & 40.6 & 25.7 & 9.8 \\
\hline Jeglówek & $54^{\circ} 14.3^{\prime}$ & $22^{\circ} 53.3^{\prime}$ & 20.1 & 27.7 & 9.3 \\
\hline Kameduł & $54^{\circ} 16.0^{\prime}$ & $22^{\circ} 52.0^{\prime}$ & 25.3 & 26.2 & 7.0 \\
\hline Kluczysko & $54^{\circ} 14.0^{\prime}$ & $22^{\circ} 52.9^{\prime}$ & 3.7 & 13.8 & 5.4 \\
\hline Kojle & $54^{\circ} 16.5^{\prime}$ & $22^{\circ} 53.5^{\prime}$ & 17.3 & 32.3 & 9.7 \\
\hline Kopane & $54^{\circ} 14.9^{\prime}$ & $22^{\circ} 54.3^{\prime}$ & 16.2 & 18.8 & 5.7 \\
\hline Krejwelek & $54^{\circ} 16.3^{\prime}$ & $22^{\circ} 55.1^{\prime}$ & 5.5 & 8.8 & 2.8 \\
\hline Linówek & $54^{\circ} 13.4^{\prime}$ & $22^{\circ} 50.4^{\prime}$ & 2.9 & 5.9 & 2.4 \\
\hline Okrągłe & $54^{\circ} 16.0^{\prime}$ & $22^{\circ} 54.4^{\prime}$ & 15.0 & 7.4 & 4.3 \\
\hline Perty & $54^{\circ} 16.4^{\prime}$ & $22^{\circ} 53.9^{\prime}$ & 19.5 & 32.6 & 7.4 \\
\hline Pobondzie & $54^{\circ} 18.7^{\prime}$ & $22^{\circ} 56.8^{\prime}$ & 53.1 & 10.0 & 3.6 \\
\hline Pogorzałek & $54^{\circ} 16.4^{\prime}$ & $22^{\circ} 50.3^{\prime}$ & 5.8 & 17.6 & 5.9 \\
\hline Postawelek & $54^{\circ} 17.0^{\prime}$ & $22^{\circ} 56.6^{\prime}$ & 3.4 & 4.0 & 2.0 \\
\hline Przechodnie & $54^{\circ} 16.7^{\prime}$ & $22^{\circ} 55.5^{\prime}$ & 23.9 & 5.4 & 3.1 \\
\hline Snouda & $54^{\circ} 15.1^{\prime}$ & $22^{\circ} 53.7^{\prime}$ & 0.47 & 4.5 & 2.0 \\
\hline Szurpiły & $54^{\circ} 13.8^{\prime}$ & $22^{\circ} 53.6^{\prime}$ & 84.4 & 47.1 & 11.2 \\
\hline Udziejek & $54^{\circ} 15.2^{\prime}$ & $22^{\circ} 53.3^{\prime}$ & 7.0 & 6.9 & 3.3 \\
\hline Wodziłki & $54^{\circ} 14.5^{\prime}$ & $22^{\circ} 50.9^{\prime}$ & 3.7 & 5.4 & 3.1 \\
\hline
\end{tabular}

Samples were taken once a year, during the summer stagnation period. The period was chosen by Karabin (1985) as best for comparative analysis of the zooplankton because of the stability of summer communities being under the influence of mostly trophic factors.

To assess changes in trophic state of the studied lakes the following rotifer trophic state indices $\left(\mathrm{TSI}_{\mathrm{ROT}}\right.$ ) were used (Ejsmont-Karabin 2012): (1) rotifer numbers, (2) total biomass of rotifer community, (3) percentage of bacterivores in total rotifer numbers, (4) ratio of biomass to numbers, (5) percentage of the tecta form in the population of Keratella cochlearis, (6) contribution of species which indicate high trophic state in the indicatory group numbers.

$\mathrm{TSI}_{\mathrm{ROT}}$ values under 45 indicate mesotrophy, $\mathrm{TSI}_{\text {ROT }}$ values between 45and 55 - meso-eutrophy, those between 55 and 65 - eutrophy, and those above 65 indicate hypertrophy.

\section{Results and discussion}

Rotifer communities in Suwalki lakes studied in 2015 were mostly of extremely low densities, often below $200 \mathrm{ind} . \mathrm{dm}^{-3}$. The communities were dominated by detritophagous Keratella cochlearis (Gosse) and algivorous Polyarthra remata Skorikov and P. vulgaris Carlin. The exceptions were lakes Kluczysko and Udziejek with a high density of small bacteriophage Anuraeopsis fissa (Gosse) (Fig. 1).

The communities of rotifers indicative of lake trophy consisted mostly of species that signal low trophy in lakes Boczniel, Kamenduł, Perty and Pogorzałek (Fig. 2). Single species indicating a low trophic state were found in lakes Kojle and Łuśnin (Gastropus stylifer Imhof) and in Lake Purwinek (Conochilus hippocrepis (Schrank)). Six lakes consisted of an indicatory set of species dominated by those typical for high trophy. Five 


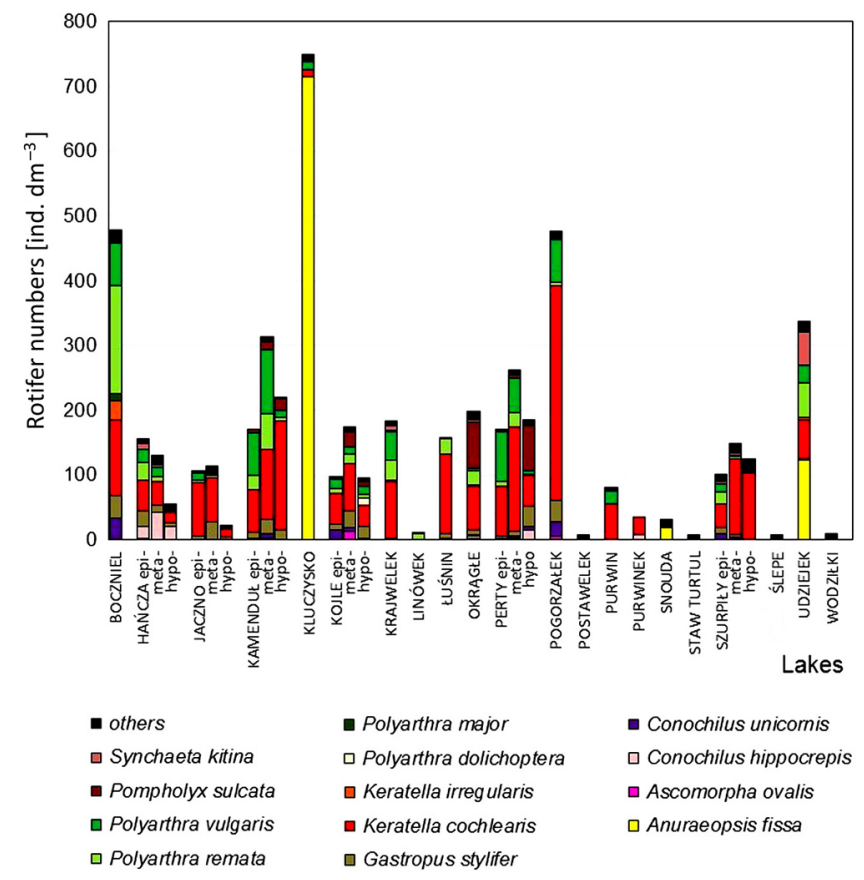

Fig. 1. Rotifer density and species structure in lakes of the Suwalki Lanscape Park in summer 2015. In Lakes Kamenduł, Kojle and Perty data are given for epi-, meta- and hypolimnion (from left to right)

lakes were devoid of any rotifer indicators of trophy (Fig. 2).

Data on rotifer abundance and species composition in the epilimnion of the lakes were used to establish values of parameters enabling an assessment of lake trophy (Table 2). The studies covered the years 19831985 (Karabin and Ejsmont-Karabin 1993, 1994), 2009 (Jekatierynczuk-Rudczyk et al. 2014) and 2015. The comparison revealed that rotifer densities observed in the years 1983-1985 were often markedly higher than in 2014 or 2015. A particularly strong decrease was noted in lakes: Boczniel, Czarne, Gulbin, Kluczysko,
Kopane, Okrągłe, Postawelek, Szurpiły i Udziejek. Some fluctuations without clear trends together with the highest density achieved in the year 1995 were observed in Lake Perty (Table 2).

Distinct changes within the ca 30 years of the study were also seen in species structure, biomass, mean weight of one individual and the presence of bacteriovores in the community of Rotifera (Table 2). In general, the tecta form of Keratella cochlearis occurred rarely, and in 2015 in lakes Linówek, Postawelek and Wodziłki both forms (typica and tecta) of the species were absent.

Although the 30-32-year changes in the species structure of rotifer communities were generally significant, they did not usually lead to the total replacement of species, instead the changes occurred in their participation in the total densities (Fig. 3). Exceptions were Lake Kluczysko, where Gastropus stylifer, Filinia longiseta (Ehrenberg) and Keratella cochlearis were replaced by Anuraeopsis fissa, and Lake Postawelek, where $A$. fissa and $K$. cochlearis were replaced by Squtinella $s p$. and Conochiloides dossuarius(Skorikov) .

According to rotifer indices of lake trophy, most of the lakes surveyed in the years 2009-2015 are now meso-eutrophic. They represent $77 \%$ of the lakes, while $14 \%$ can be considered as mesotrophic, and 9\% are eutrophic. However, even in the latter there is still relatively moderate eutrophy. The trophic state of the lakes studied in 1983-1985, estimated by means of the same method, was much higher (Fig. 4). At that time lakes with low eutrophy dominated (48\% of the lakes), but the share of meso-eutrophic lakes was similarly high (43\%). Only two lakes: Hańcza and Szelment Wielki were mesotrophic.

Over the 25-32 years there were no changes in the structure and abundance of rotifer communities in $75 \%$ of the lakes of the Suwalki Landscape Park that

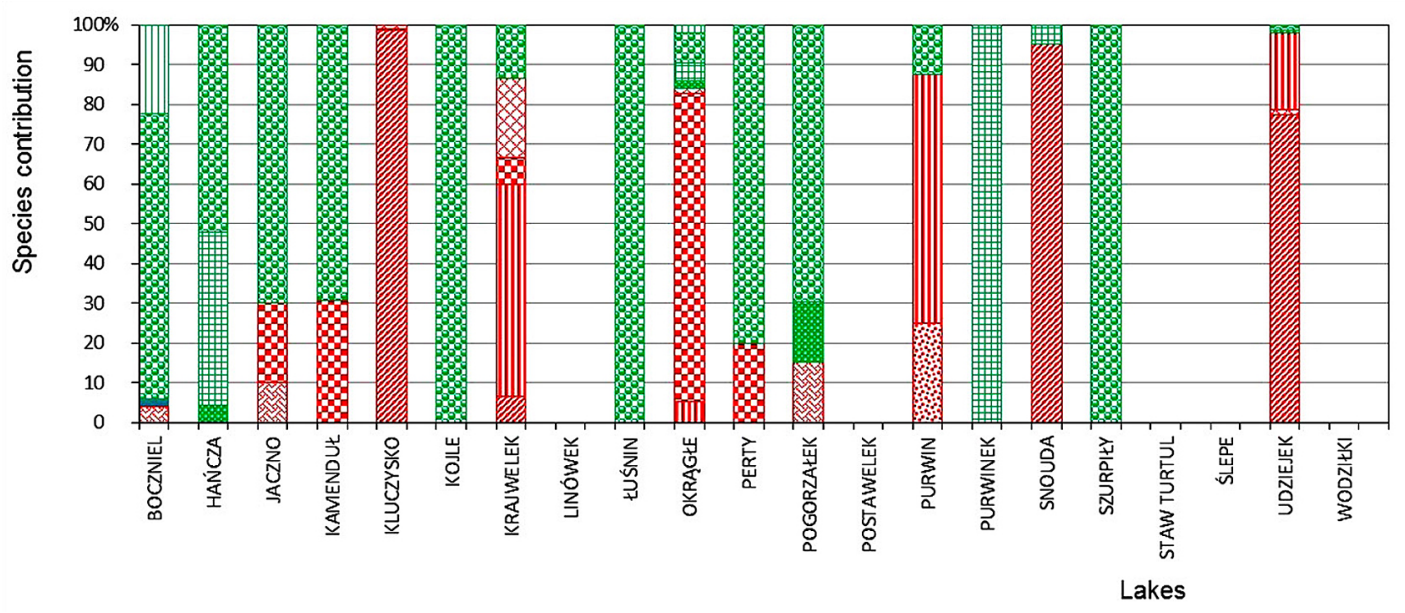

$\square$ Polyarthra major Gastropus stylifer $\boxplus$ Conochilus hippocrepis Ascomorpha ovalis Ascomorpha ecaudis $\checkmark$ Trichocerca pusilla 口Pompholyx sulcata mKeratella tecta Filinia longiseta Brachionus angularis $\unrhd$ Anuraeopsis fissa

Fig. 2. Contribution (\%) of species indicating low and high trophic state in the indicatory group numbers 
Table 2. Parameters used to assess trophic status of lakes (Ejsmont-Karabin 2012) and based on density and species composition of rotifer communities. Explanations: $\mathrm{N}$ - rotifer numbers (ind. $\left.\mathrm{dm}^{-3}\right)$; B - total biomass of rotifer community $\left(\mathrm{mg} \mathrm{ww} \mathrm{dm}^{-3}\right)$; BAC - percentage of bacterivores in total rotifer numbers (\%); TECTA - percentage of the tecta form in the population of Keratella cochlearis (\%); B:N - ratio of biomass to numbers ( $\mu \mathrm{g}$ ww ind. ${ }^{-1}$ ); IHT - contribution of species which indicate high trophy in the indicatory group numbers (\%)

\begin{tabular}{|c|c|c|c|c|c|c|c|}
\hline \multirow{2}{*}{ Lake } & \multirow{2}{*}{ Year } & \multicolumn{6}{|c|}{ Parameter } \\
\hline & & $\mathrm{N}$ & $\mathrm{B}$ & BAC & TECTA & $\mathrm{B}: \mathrm{N}$ & $\mathrm{IHT}$ \\
\hline Łuśnin & 2015 & 159 & 0.02802 & 77.4 & 0.0 & 0.176 & 0.0 \\
\hline Purwinek & 2015 & 36 & 0.00936 & 77.8 & 0.0 & 0.260 & - \\
\hline Purwin & 2015 & 81 & 0.01649 & 72.8 & 9.1 & 0.204 & 87.5 \\
\hline \multicolumn{8}{|c|}{ Drainage basin of Czarna Hańcza } \\
\hline \multirow[t]{3}{*}{ Boczniel } & 1984 & 2743 & 0.62413 & 22.3 & 0.0 & 0.228 & 46.6 \\
\hline & 2009 & 36 & 0,01829 & 30.6 & 0.0 & 0.508 & 6.7 \\
\hline & 2015 & 477 & 0.14983 & 37.7 & 0.0 & 0.314 & 0.4 \\
\hline Jegliniszki & 1984 & 2112 & 0.31127 & 45.3 & 0.0 & 0.147 & 100.0 \\
\hline \multirow[t]{5}{*}{ Hańcza } & 1983 & 56 & 0.02704 & 1.8 & 0.0 & 0.483 & 0.0 \\
\hline & 1995 & 1644 & 0.42422 & 39.4 & 0.0 & 0.258 & 1.5 \\
\hline & 2002 & 153 & 0.06553 & 11.1 & 0.0 & 0.428 & 0.0 \\
\hline & 2009 & 255 & 0.08907 & 32.9 & 0.0 & 0.349 & 0.0 \\
\hline & 2015 & 163 & 0.10022 & 28.7 & 0.0 & 0.615 & 0.0 \\
\hline \multicolumn{8}{|c|}{ Drainage basin of Szelmentka } \\
\hline Szelment Wielki & 1985 & 57 & 0.03292 & 3.5 & 0.0 & 0.578 & 0.0 \\
\hline Szelment Mały & 1985 & 466 & 0.16532 & 28.8 & 0.8 & 0.355 & 1.5 \\
\hline Itgieł & 1985 & 1726 & 0.27149 & 59.2 & 21.5 & 0.157 & 96.2 \\
\hline Ślepe & 2015 & 8 & 0.00399 & 37.5 & 0.0 & 0.499 & - \\
\hline Kupowo & 1985 & 2037 & 0.42459 & 29.2 & 36.3 & 0.208 & 72.1 \\
\hline \multicolumn{8}{|c|}{ Drainage basin of Szeszupa } \\
\hline \multirow[t]{2}{*}{ Czarne } & 1985 & 1946 & 0.55874 & 23.1 & 0.9 & 0.287 & 8.7 \\
\hline & 2014 & 120 & 0.02723 & 26.7 & 0.0 & 0.227 & 66.7 \\
\hline \multirow[t]{2}{*}{ Gulbin } & 1983 & 2033 & 0.55963 & 45.2 & 40.9 & 0.275 & 56.3 \\
\hline & 2009 & 496 & 0.15219 & 74.0 & 27.8 & 0.307 & 93.9 \\
\hline \multirow[t]{3}{*}{ Jaczno } & 1984 & 206 & 0.05189 & 31.6 & 0.0 & 0.252 & 9.7 \\
\hline & 2009 & 25 & 0.00687 & 24.0 & 0.0 & 0.275 & 50.0 \\
\hline & 2015 & 113 & 0.04003 & 71.1 & 0.0 & 0.354 & 18.8 \\
\hline \multirow[t]{2}{*}{ Jeglówek } & 1983 & 850 & 0.22922 & 14.1 & 0.0 & 0.270 & 0.0 \\
\hline & 2009 & 438 & 0.10950 & 39.7 & 0.0 & 0.250 & 0.0 \\
\hline \multirow[t]{3}{*}{ Kamenduł } & 1984 & 447 & 0.12188 & 22.1 & 9.5 & 0.273 & 39.0 \\
\hline & 2009 & 72 & 0.02088 & 61.1 & 42.3 & 0.290 & 86.3 \\
\hline & 2015 & 177 & 0.04462 & 39.5 & 0.0 & 0.252 & 30.8 \\
\hline \multirow[t]{3}{*}{ Kluczysko } & 1983 & 1948 & 0.41748 & 47.2 & 1.6 & 0.214 & 58.8 \\
\hline & 2009 & 95 & 0.02153 & 61.1 & 23.5 & 0.227 & 94.1 \\
\hline & 2015 & 749 & 0.03894 & 96.8 & 30.0 & 0.052 & 100.0 \\
\hline \multirow[t]{3}{*}{ Kojle } & 1984 & 268 & 0.06317 & 17.9 & 0.0 & 0.236 & 0.0 \\
\hline & 2009 & 79 & 0.01844 & 39.2 & 0.0 & 0.233 & 14.3 \\
\hline & 2015 & 97 & 0.02868 & 49.5 & 0.0 & 0.296 & 0.0 \\
\hline \multirow[t]{2}{*}{ Kopane } & 1983 & 1022 & 0.27937 & 20.5 & 6.4 & 0.273 & 16.3 \\
\hline & 2009 & 23 & 0.00488 & 52.2 & 0.0 & 0.212 & 100.0 \\
\hline \multirow[t]{3}{*}{ Krajwelek } & 1983 & 3826 & 1.02632 & 43.0 & 37.3 & 0.268 & 62.2 \\
\hline & 2009 & 178 & 0.04272 & 91.0 & 35.3 & 0.240 & 98.3 \\
\hline & 2015 & 187 & 0.03904 & 49.2 & 9.1 & 0.209 & 86.7 \\
\hline \multirow[t]{2}{*}{ Linówek } & 2009 & 417 & 0.09866 & 39.1 & 0.0 & 0.237 & 12.7 \\
\hline & 2015 & 11 & 0.00236 & 18.2 & - & 0.215 & - \\
\hline \multirow[t]{3}{*}{ Okrągłe } & 1983 & 1434 & 0.37741 & 36.3 & 21.6 & 0.263 & 54.1 \\
\hline & 2009 & 462 & 0.09486 & 71.4 & 33.1 & 0.205 & 98.5 \\
\hline & 2015 & 201 & 0.04663 & 69.7 & 7.4 & 0.232 & 83.9 \\
\hline
\end{tabular}




\begin{tabular}{|c|c|c|c|c|c|c|c|}
\hline \multirow{2}{*}{ Lake } & \multirow{2}{*}{ Year } & \multicolumn{6}{|c|}{ Parameter } \\
\hline & & $\mathrm{N}$ & B & BAC & TECTA & $\mathrm{B}: \mathrm{N}$ & IHT \\
\hline \multirow[t]{5}{*}{ Perty } & 1984 & 224 & 0.06249 & 17.9 & 0.0 & 0.279 & 0.0 \\
\hline & 1995 & 631 & 0.13941 & 41.9 & 4.2 & 0.221 & 78.9 \\
\hline & 2009 & 170 & 0.04125 & 41.8 & 0.0 & 0.243 & 53.3 \\
\hline & 2012 & 139 & 0.04668 & 38.1 & 0.0 & 0.336 & 30.9 \\
\hline & 2015 & 176 & 0.05284 & 43.8 & 0.0 & 0.300 & 16.7 \\
\hline Pobondzie & 1983 & 1833 & 0.33739 & 49.4 & 13.9 & 0.184 & 94.8 \\
\hline \multirow[t]{2}{*}{ Pogorzałek } & 2009 & 127 & 0.02467 & 81.1 & 2.4 & 0.194 & 91.3 \\
\hline & 2015 & 483 & 0.10501 & 70.0 & 0.0 & 0.217 & 14.9 \\
\hline \multirow[t]{3}{*}{ Postawelek } & 1983 & 2730 & 0.78706 & 56.1 & 39.9 & 0.288 & 94.4 \\
\hline & 2009 & 61 & 0.01252 & 72.1 & 12.1 & 0.205 & 91.7 \\
\hline & 2015 & 8 & 0.00269 & 12.5 & - & 0.336 & - \\
\hline Przechodnie & 1983 & 1638 & 0.30300 & 64.3 & 24.4 & 0.185 & 86.5 \\
\hline \multirow[t]{2}{*}{ Snouda } & 2009 & 80 & 0.02296 & 62.5 & 10.9 & 0.287 & 50.0 \\
\hline & 2015 & 36 & 0.00586 & 58.3 & 0.0 & 0.163 & 95.0 \\
\hline \multirow[t]{3}{*}{ Szurpiły } & 1983 & 972 & 0.25994 & 10.3 & 2.1 & 0.267 & 10.3 \\
\hline & 2009 & 117 & 0.02798 & 51.3 & 3.4 & 0.239 & 12.5 \\
\hline & 2015 & 140 & 0.05278 & 57.6 & 0.6 & 0.377 & 7.9 \\
\hline \multirow[t]{3}{*}{ Udziejek } & 1983 & 1673 & 0.42510 & 46.7 & 27.6 & 0.254 & 63.7 \\
\hline & 2009 & 714 & 0.13714 & 87.3 & 15.2 & 0.192 & 97.3 \\
\hline & 2015 & 353 & 0.05682 & 53.5 & 51.7 & 0.161 & 98.1 \\
\hline Wodziłki & 2015 & 10 & 0.01120 & 40.0 & - & 1.120 & - \\
\hline
\end{tabular}

would indicate a decline in trophy of the lakes under study (Fig. 4). However, in lakes where the strongest decline of these values was recorded, values of individual indicative parameters greatly varied in 2015 , which resulted in very high values of standard deviation. This seems to point to certain processes currently affecting the trophic state of lakes, which may suggest that the status of rotifer communities in these lakes is dependent on non-trophic factors. In this case the assessment of the trophic status of lakes would not sufficiently illustrate their ecological status. According to Kratz et al. (1987) taxa that exhibit large variability among sites are sensitive indicators of change in an ecosystem. Rotifers are among such taxa (Ejsmont-Karabin 2012). This has also been demonstrated in long-term studies on Lake Vortsjarv (Haberman and Haldna 2014), where rotifer indices increased in parallel with increasing trophic level. The complicated character of factors influencing the productivity of the lakes under study, as described by Górniak et al. (2016), and especially the important role of hydrology, is reflected in both long- and shortterm changes in rotifer indices of lake trophy. The relatively high water retention time noted in 2015 (due to an exceptionally warm and dry summer), and good oxygenation of the hypolimnion zones, made internal phosphorus input impossible (Górniak et al. 2016).

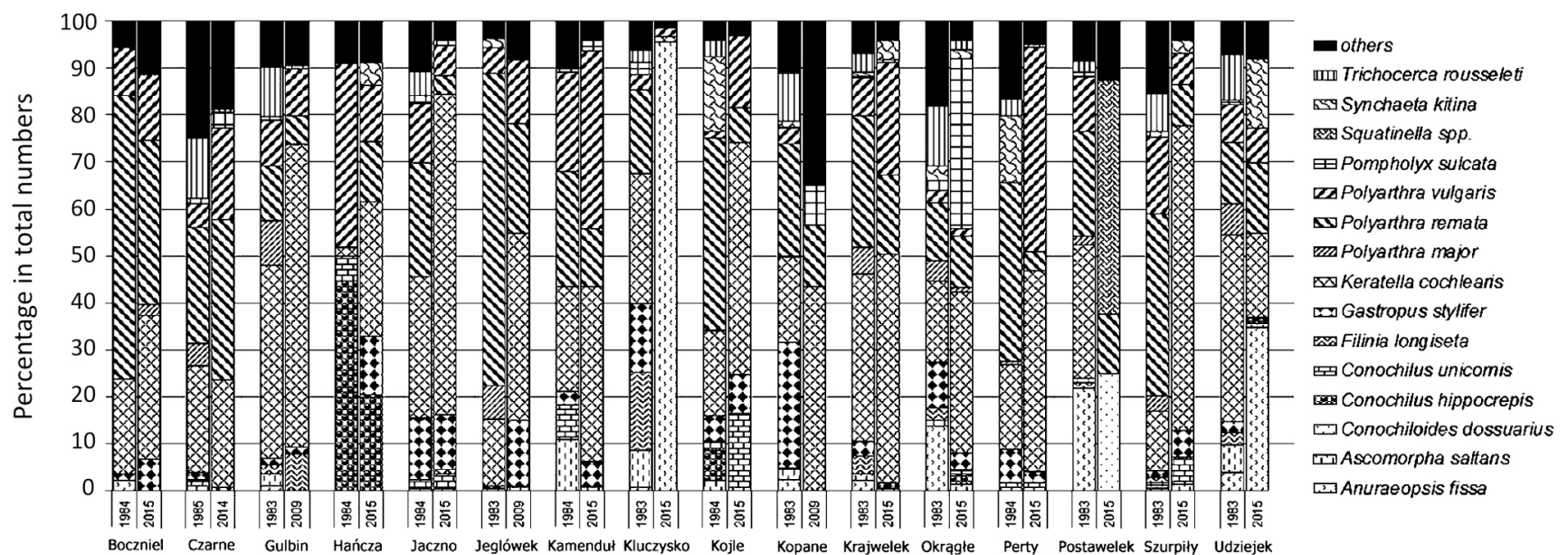

Fig. 3. Comparison of species structure of rotifer communities in the epilimnion of lakes in the years 1983-1985 with the communities noted in the years 2009 or 2015 


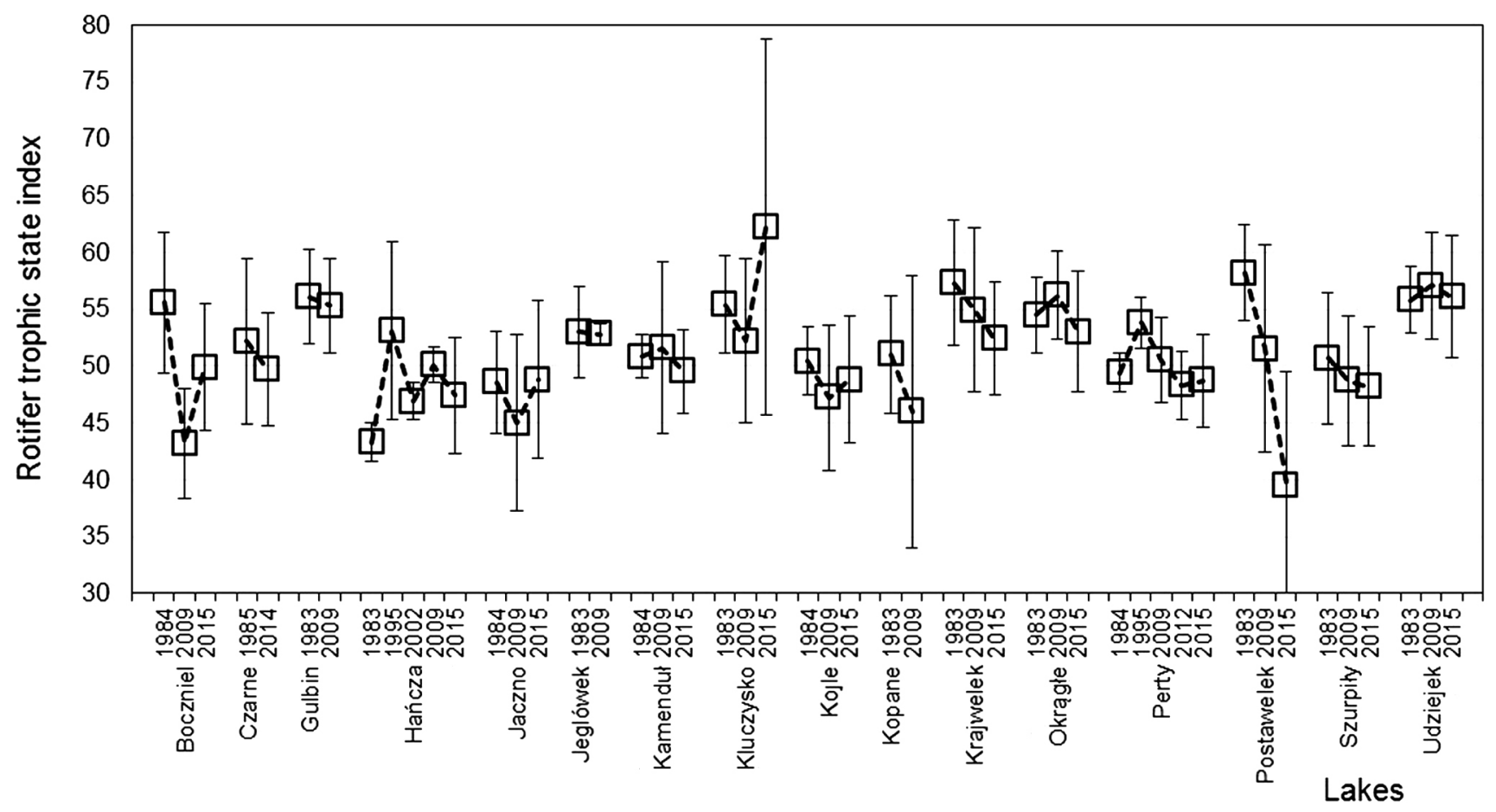

Fig. 4. Long-term changes in rotifer index of trophic state of Suwalki lakes

This may explain the recently observed low trophy of the studied lakes as reflected in the values of rotifer indices.

\section{Conclusions}

The results of the 30 -year studies confirmed to some extent the tested hypothesis as the trophic status of the lakes remained relatively low, and some of them are currently even lower than noted 30 years earlier. Most of the lakes recently studied are meso-eutrophic or moderately eutrophic. However, high deviation of particular rotifer indices may result from impact of environmental factors other than trophic ones.

\section{Acknowledgements}

The study was partly supported by the Ministry of Science and Higher Education (MNiSW) under project number NN306275135.

\section{References}

Borowiak D., Nowiński K., Grabowska K., 2016, A new bathymetric survey of the Suwałki Landscape Park lakes, Limnol. Rev. 16(4): 185-197.

Ejsmont-Karabin J., 2012, The usefulness of zooplankton as lake ecosystem indicators: rotifer trophic state index, Pol. J. Ecol. 60(2): 339-350.
Ejsmont-Karabin J., 2013, An analysis based on rotifer indices of the effects of water and sewage management on water quality in the system of interconnected glacial lakes, Limnol. Rev. 13(4): 191-194.

Gannon J.E., Stemberger R.S., 1978, Zooplankton (especially Crustaceans and Rotifers) as indicators of water quality, Trans. Amer. Microsc. Soc. 97(1): 16-35.

Górniak A., Więcko A., Karpowicz M., 2016, Changes in the trophic status of lakes in the Suwałki Landscape Park (NE Poland), Limnol. Rev. 16(4): 221-227.

Haberman J., Haldna M., 2014, Indices of zooplankton community as valuable tools in assessing the trophic state and water quality of eutrophic lakes: long term study of Lake Võrtsjärv, J. Limnol. 73(2): 263-273.

Jańczak J. (ed.), 1999, Atlas jezior Polski. Tom 3: Jeziora Pojezierza Mazurskiego i Polski południowej (The atlas of Polish lakes. Vol. 3: Masurian lakes and the southern part of Poland), Bogucki Wydaw. Nauk., Poznań: 240 pp (in Polish, English summary).

Jekatierynczuk-Rudczyk E., Zieliński P., Grabowska M., Ejsmont-Karabin J., Karpowicz M., Więcko A., 2014, The trophic status of Suwałki Landscape Park lakes based on selected parameters (NE Poland), Environ. Monit. Assess. 186(8): 5101-5121.

Karabin A., 1985, Pelagic zooplankton (Rotatoria + Crustacea) variation in the process of lake eutrophication. I. Structural and quantitative features, Ekol. Pol. 33(4): $567-616$. 
Karabin A., Ejsmont-Karabin J., 1993, Zooplankton communities versus lake trophy in Suwałki Lanscape Park (North-eastern Poland), Ekol. Pol. 41(1-2): 237-268.

Karabin A., Ejsmont-Karabin J., 1994, Zespoły zooplanktonu jezior Suwalskiego Parku Krajobrazowego (Zooplankton communities in the lakes of Suwałki Landscape Park), [in:] Hillbricht-Ilkowska A., Wiśniewski J.R. (eds), Jeziora Suwalskiego Parku Krajobrazowego. Związki z krajobrazem, stan eutrofizacji i kierunki rozwoju (Lakes of the Suwałki Landscape Park. Links with landscape, eutrophication and protection measures), Zesz. Nauk.
Komit. „Człowiek i Środowisko” PAN 7: 215-242 (in Polish, English summary).

Karpowicz M., Górniak A., Więcko A., Cudowski A., 2016, The variability of summer phytoplankton communities in different types of lakes in Suwałki Landscape Park, Limnol. Rev. 16(4): 229-236.

Kratz T.K., Frost T.M., Magnuson J.J., 1987, Inferences from spatial and temporal variability in ecosystems: long-term zooplankton data from lakes, Amer. Nat. 129(6): 830-846.

Ochocka A., Pasztaleniec A., 2016, Sensitivity of plankton indices to lake trophic conditions, Environ. Monit. Assess. 188(11): 622 . 